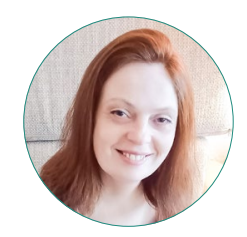

М. В. Кравцова

\title{
ПРЕДИКТОРЫ ИСТОРИЧЕСКОГО ТИПА СЕМЬИ НА ПРИМЕРЕ РОССИЙСКОЙ ИМПЕРИИ
}

\section{Правильная ссылка на статью:}

Кравцова М.В. Предикторы исторического типа семьи на примере Российской империи // Мониторинг общественного мнения: экономические и социальные перемены. 2021. № 2. C. 95-120. https://doi.org/10.14515/monitoring.2021.2.1690.

\section{For citation:}

Kravtsova M.V. (2021) Predictors of the Historical Family Type on the Example of the Russian Empire. Monitoring of Public Opinion: Economic and Social Changes. No. 2. P. 95-120. https:// doi.org/10.14515/monitoring.2021.2.1690. (In Russ.) 
ПРЕДИКТОРЫ ИСТОРИЧЕСКОГО ТИПА СЕМЬИ НА ПРИМЕРЕ РОССИЙСКОЙ ИМПЕРИИ

КРАВЦОВА Мария Владимировна кандидат социологических наук, научный сотрудник Лаборатории сравнительных социальных исследований, Национальный исследовательский университет "Высшая школа экономики", Москва, Россия

E-MAIL: maria_krav@mail.ru https://orcid.org/0000-0001-7660-2030

Аннотация. В недавних исследованиях было показано, что историческая структура семьи имеет большое значение, так как она предопределила институциональное и экономическое развитие. Данная работа посвящена изучению факторов, обуславливающих разницу в устройстве семьи в прошлом, на примере Российской империи. Анализ основан на переписи Российской империи 1897 г. и других статистических материалах того же периода, а также на всемирных географических базах данных. Всего собранная база данных содержит 829 наблюдений на уровне уездов. Мы показываем, что расширенные семьи были более распространены на территориях 1) с лучшими природными условиями для ведения сельского хозяйства и большой долей сельскохозяйственного сектора в экономике, 2) с высоким уровнем экзистенциальной незащищенности, 3) населенных этносами с сильной локальной идентичностью, которые охраняют целостность своей группы, ограничивая контакты с аутсайдерами. В то же время собственность на землю, плотность населения и религия оказались незначимыми.
PREDICTORS OF THE HISTORICAL FAMILY TYPE ON THE EXAMPLE OF THE RUSSIAN EMPIRE

Maria V. KRAVTSOVA ${ }^{1}$ - Cand. Sci. (Soc.), Research fellow of the Laboratory for Comparative Social Research

E-MAIL: maria_krav@mail.ru

https://orcid.org/0000-0001-7660-2030

\footnotetext{
1 National Research University Higher School of Economics, Moscow, Russia
}

Abstract. Recent studies have shown that historical family structure is of great importance, since it affects institutional and economic development. This paper concerns predictors of historical family type in the Russian Empire. The analysis is based on the 1987 census of the Russian Empire and other statistical materials referring to the same period, as well as on various global geographical databases. In total, the collected dataset contains 829 observations at the district level. The author shows that extended families were more widespread in areas: 1) with better natural conditions for farming and a large share of agricultural sector in the economy; 2) with a high level of existential insecurity; 3) populated by ethnicities with strong group identity, who tend to protect the integrity of their group, limiting contacts with outsiders. Land ownership, population density, and religion were found to be insignificant. 
Ключевые слова: расширенная семья, нуклеарная семья, сельское хозяйство, локальная идентичность, экзистенциальная незащищенность

Благодарность. Статья подготовлена в результате проведения исследования в рамках Программы фундаментальных исследований Национального исследовательского университета "Высшая школа экономики" (НИУ ВШЭ). Мы благодарны Н. Кирилиной, В. Козлову, А. Щербаку и другим сотрудникам Лаборатории сравнительных социальных исследований за ценные комментарии.
Keywords: extended family, nuclear family, agriculture, local identity, existential insecurity

Acknowledgments. The paper was prepared within the framework of the HSE University Basic Research Program. The author is grateful to N. Kirilina, V. Kozlov, A. Scherbak, and other members of the Laboratory for Comparative Social Research for their useful comments.

\section{І. Введение}

Согласно последним исследованиям, исторический тип семьи был одним из важных факторов институционального и экономического развития. Например, по мнению Дж. Шульца и соавторов [Schulz et al., 2019], Западной церкви удалось сместить траекторию развития европейских стран путем изменения структуры семьи и ослабления родственных связей. В результате сегодня страны Западной Европы характеризуются аббревиатурой: западные (West), образованные (Educated), индустриализированные (Industrialized), богатые (Rich) и демократичные (Democratic) (WEIRD). Существует много работ, показывающих, что историческая структура семьи повлияла на различные аспекты современной жизни. Так, доиндустриальный тип семьи сказался на экономическом развитии [Todd, 1990; Duranton, Rodríguez-Pose, Sandall, 2009], участии в политике [Alesina, Giuliano, 2011], генерализованном доверии [Alesina, Giuliano, 2011; Kravtsova, Oshchepkov, Welzel, 2018], позициях женщин и детей на рынке труда [Alesina, Giuliano, 2014], уровне образования и неравенства [Duranton et al., 2009], а также на государстве всеобщего благосостояния [Galasso, Profeta, 2012; Costa-Font, 2010].

В семье происходит первичная социализация человека и формируются его базовые ценности, многие из которых, например способность доверять незнакомым людям [Uslaner, 2000] и миру в целом [Ericson, 1993], закладываются в раннем детстве. Подобным образом отношения внутри семьи, в том числе и распределение власти, могут накладывать отпечаток на будущее и поведение ребенка. Результаты исследований, выявляющие связь между устройством семьи и социально-экономическими индикаторами, служат ярким доказательством того, что внутрисемейные ценности могут влиять на формирование общественных институтов.

Принимая во внимание, что структура семьи потенциально имеет важные последствия для общества, в данной работе мы решили сконцентрироваться на факторах, обуславливающих определенные типы семьи. В частности, на семью могут оказывать влияние географические и социально-экономические условия, 
а также важные общественные институты. Изучая предикторы доиндустриальной семьи, мы приближаемся к разгадке известного пазла "Почему именно Европа", то есть почему именно в Западной Европе зародились богатые индустриальные и демократические государства. Таким образом, наша работа позволит изучить механизм институционального развития, основанного на структуре семьи.

Мы обращаемся к исторической семье, а не к современной, главным образом потому, что хотим объяснить длительные институциональные процессы, укорененные в прошлом. Именно исторический тип семьи определил дальнейшую траекторию развития разных стран мира, поэтому он заслуживает особого внимания.

В нашей работе мы различаем нуклеарные и расширенные семьи. Нуклеарная семья включает в себя только супругов и их детей, в то время как расширенные семьи могут состоять из нескольких поколений, а также родственников по боковой линии. Расширенная семья, как правило, более иерархична. Ей присущи два типа иерархий: гендерная (власть мужа над женой) и межпоколенческая (власть старшего поколения над более молодыми). Кроме того, расширенные семьи могут достигать внушительных размеров, поэтому для них, как и для других больших социальных групп, остро стоит проблема интеграции конфликтующих интересов. По этой причине наличие строгих правил и авторитарных отношений более важно для расширенных семей, чем для нуклеарных.

Расширенные и нуклеарные семьи способствуют формированию различных ценностей. Дети, которые были социализированы в расширенных семьях, придают большее значение ответственности, лояльности и послушанию, они меньше ценят индивидуализм и личные достижения [Rosen, 1961]. Расширенные семьи предполагают властные отношения и особый тип воспитания, основанный на физических наказаниях, насмешках и повышении голоса вместо логических вербальных объяснений и положительных стимулов [Elder, Bowerman, 1963]. На страновом уровне преобладание расширенных семей коррелирует с более медленным экономическим развитием [Todd, 1990; Duranton et al., 2009] и худшим качеством институтов, включая такие явления, как коррупция [Lipset, Lenz, 2000]. Подобная дисфункция институционального развития связана с формированием в расширенных семьях сильных родственных связей, которые доминируют над интересами общества и позволяют нарушать существующие нормы и правила в угоду интересам семьи. Распространенность нуклеарных семей, в свою очередь, имеет противоположные социальные последствия.

Для изучения факторов, влияющих на распространенность расширенного и нуклеарного типов семьи, мы используем данные переписи населения Российской империи 1897 г. и другие статистические материалы того же периода, а также шейп-файлы (shapefile) с географическими данными, содержащие информацию о природных условиях. В целом собранная нами база данных содержит 829 наблюдений на уровне уездов ${ }^{1}$. Российская империя представляет прекрасную базу для подобного рода исследований, так как, с одной стороны, она включает в себя территории с различными географическими, климатическими и культурными ха-

\footnotetext{
1 Единицей эконометрического анализа является уезд Российской империи. Индикаторы экзистенциальной незащищенности, такие как доля людей, страдающих инфекционными заболеваниями, и доля убитых от числа умерших внезапно доступны лишь на уровне губерний (см. табл. 1).
} 
рактеристиками, а с другой - данный подход позволяет контролировать ряд общих для всего государства параметров. Более того, концентрируясь на регионах одного государства, мы можем собрать наибольшее число исторических показателей. Список индикаторов, доступных для разных стран, будет значительно уже, так как сбор данных является крайне времязатратным процессом, который часто бывает осложнен несовместимостью статистических стандартов.

Основываясь на результатах многомерного регрессионного анализа, мы показываем, что основными факторами преобладания расширенных семей являются природные условия, благоприятные для ведения сельского хозяйства, а также размер сельскохозяйственного сектора. Аграрное общество обеспечивало оптимальные условия для увеличения размера семьи, во-первых, потому что сельскохозяйственное производство было крайне трудоемким, а во-вторых, потому что в данном случае семья была производственной единицей. Кроме того, в нашей работе мы показываем, что представители этносов и территорий с сильной локальной идентичностью предпочитают более самодостаточные расширенные семьи, позволяющие минимизировать контакты с аутсайдерами. Наконец люди, постоянно ощущающие угрозу своему существованию и экзистенциальную незащищенность, с большей вероятностью выберут расширенную семью. Возможное объяснение заключается в том, что расширенные семьи более стабильны и менее экономически уязвимы в случае смерти одного из взрослых членов семьи.

Данная работа строится следующим образом: в разделе II мы представляем обзор литературы, который позволяет сформировать список возможных предикторов структуры семьи, а также формулируем гипотезы. Раздел III посвящен данным и методологии, результаты описаны в разделе IV, a V - заключительный.

\section{II. Факторы расширенной и нуклеарной семьи}

В этом разделе, исходя из теории, мы формулируем возможные предикторы структуры доиндустриальной семьи. Согласно историческим и этнографическим источникам, расширенная семья была продуктом аграрного общества, которое, с одной стороны, столкнулось с серьезной проблемой резкого увеличения плотности населения, а с другой стороны, нуждалось в больших семьях ввиду высокой трудозатратности сельскохозяйственного производства [Nimkoff, Middleton, 1960]. При этом известно, что в обществах охотников и собирателей преобладали нуклеарные семьи. У первобытных людей не было ни достаточно пищи, чтобы прокормить членов большой семьи, ни острой потребности в дополнительной рабочей силе внутри нее. Аналогичным образом количество расширенных семей начало резко сокращаться в значительно более поздний период развития цивилизации, когда в результате процессов индустриализации сельское хозяйство стало утрачивать свое значение, а семья перестала быть хозяйственной единицей.

Учитывая данные аргументы, можно предположить, что расширенная семья преобладала в обществах, которые раньше перешли к сельскому хозяйству и в которых оно было более развито ввиду благоприятных природных условий. Следовательно, мы выделяем ряд природных условий, которые (не) способствовали ведению сельского хозяйства и обуславливали распространение (нуклеарных) расширенных семей. 
Существует теория, основанная на археологических находках, что сельское хозяйство пришло в Европу из Плодородного полумесяца на Ближнем Востоке, распространяясь со скоростью 1 км в год [Gangal, Sarson, Shukurov, 2014]. Таким образом, расстояние от каждого конкретного уезда Российской империи до Плодородного полумесяца может быть индикатором момента перехода от охоты и собирательства к сельскому хозяйству.

Климатические условия, такие как температура и осадки, также были важными предикторами развития сельского хозяйства и, следовательно, формирования определенной структуры семьи. В частности, для производства сельскохозяйственной продукции было необходимо достаточное количество осадков и отсутствие экстремально высоких температур в летний период. Кроме того, качество почвы имело немаловажное значение.

Лесное покрытие территории могло оказывать двоякий эффект. С одной стороны, лесные массивы затрудняли ведение сельского хозяйства, так как прежде, чем землю можно было использоваться под посев, с нее должна была быть удалена вся растительность. Более того, леса, богатые растительной и животной пищей, создавали оптимальные условия для охотников и собирателей. В результате живущие в лесах племена имели меньше стимулов для перехода к аграрному обществу, что способствовало более позднему наступлению неолитической революции ${ }^{2}$. Соответственно, на лесных территориях период охоты и собирательства, связанный с нуклеарной семьей, длился дольше. Согласно представленным аргументам, на территориях, покрытых лесом, должна была преобладать нуклеарная семья.

Однако существует и противоположная гипотеза. В Российской империи лесные территории часто использовались под подсечное земледелие. Это очень трудозатратная технология, когда лес сначала срубали, а потом сжигали с целью подготовить участок для ведения сельского хозяйства. Данную работу сложно было выполнять силами нуклеарной семьи, что, в свою очередь, способствовало формированию расширенных домохозяйств [Mitterauer, 1996].

Долины рек представляли благоприятные возможности для ирригации и одновременно были первыми оазисами, в которых зарождалась неолитическая революция [Childe, 1935]. Следовательно, мы ожидаем, что в долинах рек преобладали расширенные семьи.

Горные районы, по мнению некоторых ученых, также должны были способствовать формированию расширенных семей [Kaser, 2001; Todorova, 1989], поскольку в них складывалась особая организация сельского хозяйства, предполагающая обработку удаленных друг от друга земельных участков [Webster, 1973]. Есть работы, в которых расширенные семьи связываются со скотоводством в горах и необходимостью в кооперации нескольких родственников [Mitterauer, 1996]. Другой важной причиной распространения расширенных семей считалась сложность обеспечения общественного порядка на труднодоступных территориях. Например,

\footnotetext{
2 CM.: Welzel C., Alexander A. C., Klasen S. (2017) The Cool Water Effect (Emerging New Monograph). URL: https://www. researchgate.net/project/The-Cool-Water-Effect-Civilizations-Turn-into-Human-Empowerment-emerging-new-monograph (дата обращения: 11.04.2021).
} 
в горных районах на Балканах, которые Османская империя ${ }^{3}$ контролировала с трудом, скотоводство ассоциировалось с ношением оружия и борьбой со скотокрадами [Kaser, 2012: 122]. В подобных условиях формирование расширенных семей объясняется высокой потребностью в мужской силе [Brunnbauer, 2003].

Наряду с природными условиями на структуру семьи потенциально оказывали влияние устойчивые культурные факторы, такие как религия и этничность. Протестантизм, будучи индивидуалистической религией [Jha, Panda, 2017], с большей вероятностью мог сочетаться с нуклеарной семьей, чем иерархические религии, такие как ортодоксальное христианство, ислам, иудаизм и даже католицизм.

Этническая принадлежность, несущая в себе отпечаток исторических событий и социальных отношений в прошлом, также может пролить свет на причины того или иного устройства семьи. Нередко более сильной локальной идентичностью отличались этносы, которые в ходе истории часто завоевывались и становились жертвами насилия или принудительной ассимиляционной политики, а также этносы, рассеянные по территории империи и не имевшие привязки к конкретному региону [Fouka, 2020; Rohner, Thoenig, Zilibotti, 2013] ${ }^{4}$. В качестве примеров "неблагополучных" этнических групп можно привести армян, евреев и народности, жившие на границе империи. Желание этих этнических групп не допустить ассимиляции с остальным населением, поскольку это угрожало бы их существованию, могло привести к формированию более самодостаточных расширенных семей. Данный тип семьи позволял сократить контакты за пределами родственной группы, включая взаимодействие с представителями других этносов. Кроме того, сильная групповая идентичность внутри этноса могла быть связана с крепкими родственными связями, необходимыми для поддержания целостности расширенной семьи.

В данной работе отдельно выделяется группа предикторов исторической структуры семьи, которая включает в себя социально-экономические условия в конце XIX века. Во-первых, мы обращаемся к структуре экономики, в частности к долям в ней сельского хозяйства и индустриального сектора. Мы ожидаем, что большая доля сельскохозяйственного сектора и меньшая - индустриальной экономики способствовали формированию расширенных семей. Это объясняется тем, что несельскохозяйственные виды занятости были менее трудозатратными и, как правило, осуществлялись вне семьи.

Во-вторых, мы ожидаем, что плотность населения может быть возможным предиктором структуры семьи. При этом мы исходим из того, что в условиях быстрого роста населения и ограниченности земельных ресурсов люди предпочитали жить со своими родственниками, сформировав расширенную семью.

В-третьих, в ряде работ было показано, что структура семьи связана с собственностью на землю. Так, Р. Уолл приходит к выводу, что в Западной Фландрии домохозяйства крестьян - собственников земли были больше, чем домохозяйства

\footnotetext{
з Территории Балканского полуострова находились под властью Османской империи примерно с XIV века до конца XIX века.

${ }^{4}$ См. также: Dehdari S. H., Gehring K. (2019) The Origins of Common Identity: Evidence From Alsace-Lorraine. American Economic Association. URL: https://www.aeaweb.org/articles?id=10.1257/app.20190772\&\&from=f (дата обращения: 11.04.2021).
} 
арендаторов земли [Wall, 1983]. Он объясняет это тем, что дети крестьян, арендующих землю, не имели права на наследство и могли в любой момент покинуть родительский дом. Напротив, в регионах, где земля была в собственности крестьян, наследники часто жили с родителями до их смерти. Мы ожидаем увидеть похожий паттерн и в Российской империи. В дореволюционной России много земель принадлежало крестьянским общинам. Вслед за Уоллом мы предполагаем, что расширенные семьи были более распространены в тех регионах, где земля была в частной собственности. Кроме того, в регионах, где сельскохозяйственные угодья принадлежали крестьянским общинам, семьи должны были быть больше. Данная гипотеза обусловлена политикой общин, которые перераспределяли землю между домохозяйствами в зависимости от количества взрослых мужчин в семье.

Наконец, четвертым фактором, способствующим распространению расширенных семей, можно назвать ощущение незащищенности и постоянной угрозы для жизни. Расширенные семьи были более стабильными, так как смерть одного из взрослых работников представляла меньшую угрозу для экономического благосостояния домохозяйства [Kaser, 2012]. Таким образом, в регионах с высоким уровнем смертности в результате болезней или преступности расширенные семьи были более оправданы.

Постоянное ощущение угрозы могло приводить к возникновению жестких социальных норм и строгих правил, соблюдение которых тщательно контролировалось [Gelfand, 2019]. Согласно теории Р. Инглхарта [Inglehart, 2018], при более благоприятных условиях внешней среды люди, наоборот, чувствуют бо́льшую экзистенциальную защищенность и становятся более индивидуалистичными, креативными и гибкими в отношении традиций. Строгое соблюдение правил - одно из важных условий выживания расширенных семей - не имело столь существенного значения для нуклеарных домохозяйств. Именно поэтому мы ожидаем, что атмосфера незащищенности и ощущение угрозы вкупе с наличием жестких норм могли создавать благоприятную почву для формирования расширенных семей.

Анализ приведенных выше теоретических подходов к интерпретации факторов возникновения того или иного типа семьи позволяет нам сформулировать следующие гипотезы:

1) Расстояние до Плодородного полумесяца отрицательно связано с расширенной семьей.

2) Высокая температура в летний период отрицательно связана с расширенной семьей.

3) Низкий уровень осадков отрицательно связан с расширенной семьей.

4) Качество почвы положительно связано с расширенной семьей.

5.1) Доля территории, покрытой лесом, отрицательно связана с расширенной семьей.

5.2) Доля территории, покрытой лесом, положительно связана с расширенной семьей.

6) Расстояние до ближайшей реки положительно связано с расширенной семьей.

7) Наличие гор положительно связано с расширенной семьей. 
8.1) Протестантизм отрицательно связан с расширенной семьей.

8.2) Иерархические религии положительно связаны с расширенной семьей.

9) Доля людей, принадлежащих к "неблагополучным" этносам с сильной групповой идентичностью, положительно связана с расширенной семьей.

10) Размер несельскохозяйственного сектора экономики отрицательно связан с расширенной семьей.

11) Плотность населения положительно связана с расширенной семьей.

12.1) Доля сельскохозяйственной земли в частной собственности положительно связана с расширенной семьей.

12.2) Доля сельскохозяйственной земли в собственности крестьянских общин положительно связана с расширенной семьей.

13) Экзистенциальная незащищенность и угроза жизни положительно связаны с расширенной семьей.

\section{III. Данные и методология}

Данные

Зависимой переменной в нашем исследовании выступает средний размер семейного домохозяйства, взятый из переписи Российской империи 1897 г. В данный показатель включены только те его члены, которые относятся к родственной группе. К сожалению, имеющиеся данные не позволяют отличать нуклеарные семьи с большим количеством детей от расширенных домохозяйств. Чтобы решить эту проблему, мы вводим в качестве контрольной переменной показатель рождаемости: «количество детей (0-4 лет) на женщину фертильного возраста (15-44)".

В нашей эконометрической модели мы используем ряд независимых переменных, которые отражают предикторы структуры исторической семьи. Все они кратко представлены в таблице 1. Сводная статистика по всем переменным, используемым в работе, приведена в Приложении.

Таблица 1. Основные независимые переменные

\begin{tabular}{|c|c|c|}
\hline Переменная & Источник & Методы расчета \\
\hline $\begin{array}{l}\text { Расстояние } \\
\text { до Плодородного } \\
\text { полумесяца }\end{array}$ & $\begin{array}{l}\text { Вслед за К. Гангалом } \\
\text { [Gangal et al., 2014] мы } \\
\text { измеряем расстояние } \\
\text { до Гешера (Gesher) } \\
\text { в Израиле. Гешер был } \\
\text { одним из независимых цен- } \\
\text { тров зарождения сельского } \\
\text { хозяйства, откуда оно рас- } \\
\text { пространилось в Европу. }\end{array}$ & $\begin{array}{l}\text { Расстояние между центроидами уездов } \\
\text { Российской империи и центроидом Гешера. } \\
\text { Расчеты производились с помощью программы } \\
\text { QGIS, версия 2.14.3. }\end{array}$ \\
\hline $\begin{array}{l}\text { Температура в лет- } \\
\text { ний период }\end{array}$ & $\begin{array}{l}\text { Метеорологический сервис } \\
\text { Meteoblu.com*. }\end{array}$ & $\begin{array}{l}\text { Средняя температура в самый жаркий месяц } \\
\text { года, агрегированный показатель за } 30 \text { лет } \\
\text { (1987-2017). Мы собрали данные для доступ- } \\
\text { ных современных населенных пунктов, а потом } \\
\text { сопоставили их с историческими уездами. }\end{array}$ \\
\hline
\end{tabular}




\begin{tabular}{|c|c|c|}
\hline Переменная & Источник & Методы расчета \\
\hline Осадки & $\begin{array}{l}\text { Метеорологический сервис } \\
\text { Meteoblu.com. }\end{array}$ & $\begin{array}{l}\text { Мы собрали данные для доступных современ- } \\
\text { ных населенных пунктов, а потом сопоставили } \\
\text { их с историческими уездами. }\end{array}$ \\
\hline Качество почвы & $\begin{array}{l}\text { Проект «Всемирная при- } \\
\text { годность почвы» (Global } \\
\text { Suitability of Soil Project)**. } \\
\text { Значение индекса осно- } \\
\text { вано на таких параметрах, } \\
\text { как температура, качество } \\
\text { почвы, осадки, топография. }\end{array}$ & \multirow{3}{*}{$\begin{array}{l}\text { Значения индекса были агрегированы на уров- } \\
\text { не уездов Poссийской империи с помощью } \\
\text { программы QGIS, версия 2.14.3. }\end{array}$} \\
\hline Лес & $\begin{array}{l}\text { Доля территории, покрытой } \\
\text { лесом, в досредневековый } \\
\text { период [Pongratz et al., } \\
\text { 2008]. }\end{array}$ & \\
\hline Горы & $\begin{array}{l}\text { Всемирная мультирезо- } \\
\text { люционная база данных } \\
\text { возвышенностей земли } \\
2010 \text { (The Global Multi- } \\
\text { resolution Terrain Elevation } \\
\text { Data 2010)***. }\end{array}$ & \\
\hline $\begin{array}{l}\text { Расстояние } \\
\text { до ближайшей } \\
\text { реки }\end{array}$ & $\begin{array}{l}\text { Всемирная самосогла- } \\
\text { сованная, иерархичная, } \\
\text { высокорезолюционная } \\
\text { географическая база дан- } \\
\text { ных (Global Self-consistent, } \\
\text { Hierarchical, High-resolution } \\
\text { Geography Database)****. }\end{array}$ & $\begin{array}{l}\text { Расстояние между центроидами исторических } \\
\text { уездов и ближайшей точкой на реке, рассчитан- } \\
\text { ное с помощью программы QGIS, версия 2.14.3. }\end{array}$ \\
\hline $\begin{array}{l}\text { Ортодоксальные } \\
\text { христиане; } \\
\text { протестанты; } \\
\text { мусульмане (в \%) }\end{array}$ & $\begin{array}{l}\text { Перепись Российской им- } \\
\text { перии } 1897 \text { г.***** }\end{array}$ & $\begin{array}{l}\text { Мы сравниваем протестантов с ортодоксальны- } \\
\text { ми христианами и мусульманами потому, что эти } \\
\text { две религии были наиболее распространены } \\
\text { в Российской империи. }\end{array}$ \\
\hline Этничность & $\begin{array}{l}\text { Перепись Российской } \\
\text { империи } 1897 \text { г. }\end{array}$ & $\begin{array}{l}\text { Процент людей, считающих определенный } \\
\text { язык родным. Мы используем языковые } \\
\text { группы, представленные в таблице переписи, } \\
\text { вместо отдельных языков, во-первых, потому } \\
\text { что ничтожно малое количество людей в уезде } \\
\text { говорит на отдельных языках. Во-вторых, нашей } \\
\text { целью было по возможности сократить число } \\
\text { независимых переменных в модели. Мы раз- } \\
\text { биваем языковые группы на отдельные языки } \\
\text { только когда: } \\
\text { 1) этносы, говорящие на языках одной группы, } \\
\text { территориально расположены далеко друг } \\
\text { от друга. Например, индоевропейские языки } \\
\text { (греческий, индийский, армянский); } \\
\text { 2) мы ожидаем, что эффекты различных языков } \\
\text { одной языковой группы могут быть разными. }\end{array}$ \\
\hline
\end{tabular}




\begin{tabular}{|c|c|c|}
\hline Переменная & Источник & Методы расчета \\
\hline & & $\begin{array}{l}\text { Например, литовский, жмудский (преимущест- } \\
\text { венно единонаследие), латвийский (преимуще- } \\
\text { ственно делимое наследование); } \\
\text { 3) доля людей, говорящих на одном языке } \\
\text { из группы, явно превалирует над всеми осталь- } \\
\text { ными языками. Пример - романские языки, где } \\
\text { доля говорящих на молдавском и румынском } \\
\text { языках в разы превышает число представите- } \\
\text { лей других языков. }\end{array}$ \\
\hline $\begin{array}{l}\text { (Не)сельскохозяй- } \\
\text { ственный сектор } \\
\text { экономики }\end{array}$ & $\begin{array}{l}\text { Перепись Российской } \\
\text { империи } 1897 \text { г. }\end{array}$ & $\begin{array}{l}\text { Первая главная компонента от грамотности } \\
\text { (\% людей } 6+, \text { которые умеют читать и писать) } \\
\text { и урбанизации (\% городского населения) }\end{array}$ \\
\hline $\begin{array}{l}\text { Плотность } \\
\text { населения }\end{array}$ & $\begin{array}{l}\text { Перепись Российской } \\
\text { империи } 1897 \text { г. }\end{array}$ & Людей/км² \\
\hline $\begin{array}{l}\text { Собственность } \\
\text { на землю }\end{array}$ & $\begin{array}{l}\text { Данные "Статистического } \\
\text { временника Российской } \\
\text { империи" за } 1886 \text { г.****** }\end{array}$ & $\begin{array}{l}\text { Процент земли в частной собственности, в соб- } \\
\text { ственности общины, императорской семьи } \\
\text { и государства }\end{array}$ \\
\hline $\begin{array}{l}\text { Экзистенциальная } \\
\text { защищенность }\end{array}$ & $\begin{array}{l}\text { 1) Данные “Временника } \\
\text { Центрального статисти- } \\
\text { ческого комитета МВД" } \\
\text { за } 1988-1893 \text { гг.*******; } \\
\text { 2) Данные “Статистического } \\
\text { ежегодника России» } \\
\text { за } 1912 \text { г.******** }\end{array}$ & $\begin{array}{l}\text { 1) Процент убитых от людей, умерших внезапной } \\
\text { смертью. Главная компонента от процента уби- } \\
\text { тых мужчин и процента убитых женщин; } \\
\text { 2) Процент людей, страдающих инфекционными } \\
\text { заболеваниями в } 1909 \text { г. }\end{array}$ \\
\hline
\end{tabular}

* Метеорологический сервис Meteoblu.com предоставляет данные о погоде высокого качества. Сервис разработан университетом Базеля (Швейцария) в 2006 г. URL: www.meteoblue.com (дата обращения: 03.04.2021).

** Подробнее см. URL: http://geoportal-glues.ufz.de/stories/globalsuitability.html (дата обращения: 03.04.2021).

*** Подробнее cм. URL: www.usgs.gov (дата обращения: 03.04.2021).

**** Подробнее см. URL: https://www.ngdc.noaa.gov/mgg/shorelines/ (дата обращения: 03.04.2021).

***** Подробнее см. Архивные фонды Первой всеобщей переписи населения Российской империи 1897 г. URL: http://arch1897.histcensus.asu.ru/ (дата обращения: 03.04.2021).

****** Поземельная собственность Европейской России 1877-78 гг. // Статистический временник Российской империи. Серия III. Выпуск 10. СПб. : Центральный статистический комитет MBД, 1886. URL: http://nipol.ucoz.ru/ load/statistika_rossijskoj_imperii/statisticheskij_vremennik_rossijskoj_imperii_1866_1890/statisticheskij_vremennik_ rossijskoj_imperii_serija_3_vypusk_10/141-1-0-2422 (дата обращения: 03.04.2021).

******* № 41: Умершие насильственно и внезапно в 1988-1893 гг. // Временник Центрального статистического комитета Министерства внутренних дел. СПб., 1888-1903. URL: http://elib.shpl.ru/ru/nodes/57575 (дата обращения: 03.04.2021).

******** Статистический ежегодник России 1912 г. (год девятый). СПб.: Центральный статистический комитет MВД, 1913. URL: https://library6.com/books/ste912.pdf (дата обращения: 03.04.2021).

\section{Методология}

Наш анализ ограничивается выборкой Российской империи. Подобный исследовательский дизайн позволяет собрать и проанализировать наибольшее количество предикторов исторической структуры семьи, а также сократить число возможных пропущенных переменных, часто затрудняющих межстрановое сравнение. Единицей анализа выступает исторический уезд. Максимальное число 
наблюдений составляет 829, хотя некоторые переменные недоступны для всех уездов. Нашу базу данных можно разделить на две подвыборки: полная база данных, содержащая все регионы, и сокращенная база данных, включающая в себя территорию европейской части России. Индикаторы экзистенциальной защищенности доступны только на уровне губерний: процент убитых - 86 наблюдений, процент людей, страдающих инфекционными заболеваниями,- 91 наблюдение (подробнее см. Приложение).

В качестве основного метода эконометрического анализа в нашей работе используется многомерная регрессионная модель, где зависимой переменной выступает средний размер семьи. Мы имеем список предикторов, которые могут коррелировать друг с другом. Включение всех переменных в модель одновременно создает риск недостаточности вариации для выявления определенных эффектов. Однако, добавляя переменные в модель последовательно, можно столкнуться с еще более серьезной проблемой: если в ней не будут учтены важные контрольные переменные, можно получить смещенные коэффициенты и сделать ошибочные выводы. Следуя работе Д. Трейсмана [Treisman, 2000], столкнувшегося с аналогичной проблемой, мы предпочитаем взять на себя первый риск. Мы включаем в модель все необходимые контрольные переменные и при этом следим, чтобы фактор инфляции дисперсии (VIF) не превышал значение 5.

Некоторые из предикторов, такие как экономическое развитие или плотность населения, могут быть эндогенны, поскольку не только они могут влиять на структуру семьи, но и структура семьи может влиять на них. Чтобы снизить эндогенность, мы сначала включаем в регрессию экзогенные факторы, отражающие природные условия, затем - культурные факторы, такие как религия и этничность, и в последнюю очередь - социально-экономические условия в конце XIX века. Переменные этничности сильно коррелируют с религией и с расстоянием до Гешера, что приводит к росту VIF, поэтому в регрессионную модель они включены по отдельности.

\section{IV. Результаты}

Распределение зависимой переменной по губерниям представлено на рисунке 1. Малые семьи преобладали в прибалтийских губерниях, на приграничных территориях с другими странами, для которых был характерен западноевропейский тип семьи, основанный на единонаследии. Сравнительно небольшой размер семьи наблюдался также в столичных губерниях с высокой долей индустриализации и урбанизации: Московской и Санкт-Петербургской. Наибольший размер семьи встречается в Могилевской губернии, частично занимающей историческую область Полесье, известную своей сильной локальной идентичностью. Кроме того, расширенные семьи были распространены в губерниях, находящихся на территории Армении - региона с сильной этнической идентичностью. Наконец, вполне ожидаемо большой размер семьи был характерен для черноземных сельскохозяйственных губерний.

Результаты проверки большинства гипотез с помощью регрессионного анализа представлены в таблице 2, в то время как таблица 3 посвящена анализу влияния этносов. Полученные результаты показывают, что расширенная семья связана с распространением сельского хозяйства и косвенными признаками 
более ранней неолитической революции. Расширенные домохозяйства встречаются в большем количестве в регионах с обильными осадками (гипотеза 3) и в долинах рек (гипотеза 6). Мы находим ожидаемую отрицательную корреляцию между расстоянием до Гешера и расширенной семьей (гипотеза 1). Однако этот результат не реплицируется во всех спецификациях.

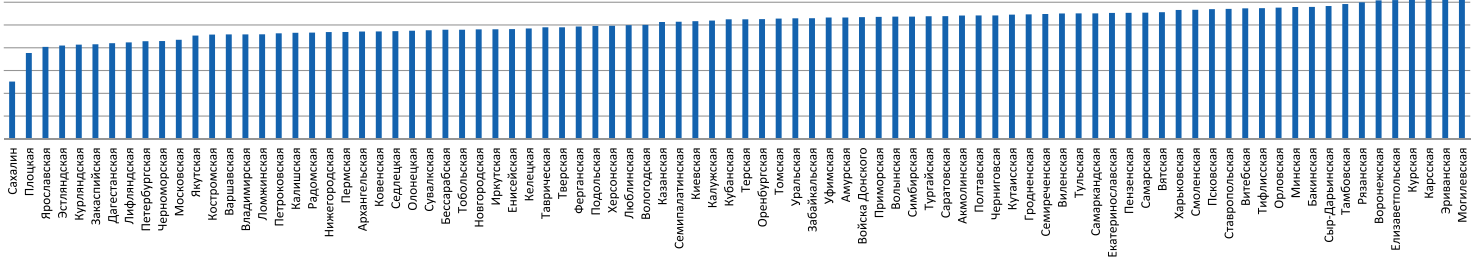

Рис. 1. Средний размер семьи, агрегированный по губерниям

Наиболее сильным предиктором расширенной семьи согласно размеру $\beta$-коэффициента оказывается доля земли, покрытая лесом в досредневековый период. В лесных регионах мы наблюдаем меньший размер домохозяйств. Это говорит о том, что сложные условия для ведения сельского хозяйства и более поздний переход от охоты и собирательства к земледелию и животноводству (гипотеза 5.1) в лесных районах с большей вероятностью объясняют структуру семьи, чем трудозатратное подсечное земледелие, указывающее на противоположную связь (гипотеза 5.2). Полученный результат остается устойчивым при контроле общинного и частного землепользования. В данном случае важно учитывать этот фактор, потому что крестьянские общины способствовали большей кооперации между семьями и тем самым снижали потребность в увеличении размера семьи в районах подсечного земледелия.

Доля несельскохозяйственного сектора отрицательно связана с расширенной семьей (гипотеза 10). Данный результат служит дальнейшим подтверждением того, что она является атрибутом аграрного общества и теряет свою значимость с приходом индустриальной революции.

Качество почвы оказывает значимый положительный эффект на размер домохозяйства (гипотеза 4) до тех пор, пока мы не контролируем долю (не)сельскохозяйственного сектора (см. табл. 2, спецификации 1 и 2). Вероятным объяснением может быть то, что развитие сельского хозяйства - единственный канал, связывающий качество почвы и размер семьи. После того как мы учитываем этот канал, качество почвы становится статистически незначимым. Полученный результат не реплицируется на сокращенной выборке для европейской части Российской империи, поэтому следует осторожно относиться к его интерпретации.

Наша модель показывает, что важно не только то, насколько распространено сельское хозяйство, но и какой его тип характерен для того или иного региона. Гипотеза о том, что в горных районах должны быть более распространены расширенные домохозяйства ввиду особого типа земледелия и скотоводства, находит свое подтверждение на данных (гипотеза 7). 
Таблица 2. Предикторы исторического типа семьи* (результаты регрессионного анализа методом наименьших квадратов (МНК))

\begin{tabular}{|c|c|c|c|c|c|}
\hline 3П: Средний размер семьи & (1) & (2) & (3) & (4) & (5) \\
\hline \multirow[t]{2}{*}{ Возвышенность } & $0,200 * * *$ & $0,169 * * *$ & $0,133 * *$ & $0,103 *$ & $-0,010$ \\
\hline & $(0,063)$ & $(0,066)$ & $(0,062)$ & $(0,061)$ & $(0,311)$ \\
\hline \multirow[t]{2}{*}{ Пригодность почвы } & $0,137 * * *$ & $0,116 * *$ & 0,003 & $-0,017$ & $-0,136 * *$ \\
\hline & $(0,056)$ & $(0,060)$ & $(0,062)$ & $(0,070)$ & $(0,091)$ \\
\hline \multirow[t]{2}{*}{$\begin{array}{l}\text { Средняя температура в са- } \\
\text { мый жаркий месяц года }\end{array}$} & 0,003 & $-0,066$ & $-0,063^{*}$ & $-0,046$ & $-0,058 * *$ \\
\hline & $(0,014)$ & $(0,017)$ & $(0,010)$ & $(0,010)$ & $(0,009)$ \\
\hline \multirow[t]{2}{*}{$\begin{array}{l}\text { Средний уровень осадков } \\
\text { в самый сухой месяц года }\end{array}$} & 0,102 & $0,142 *$ & $0,111 *$ & $0,160 * *$ & $0,141 * * *$ \\
\hline & $(0,007)$ & $(0,008)$ & $(0,007)$ & $(0,008)$ & $(0,010)$ \\
\hline \multirow[t]{2}{*}{$\begin{array}{l}\text { Доля земли, покрытой лесом } \\
\text { в досредневековые времена }\end{array}$} & $-0,151 * * *$ & $-0,168 * * *$ & $-0,196 * * *$ & $-0,202 * * *$ & $-0,234 * * *$ \\
\hline & $(0,044)$ & $(0,046)$ & $(0,043)$ & $(0,043)$ & $(0,063)$ \\
\hline \multirow[t]{2}{*}{$\begin{array}{l}\text { Менее } 50 \text { км до ближайшей } \\
\text { реки }\end{array}$} & $0,121 * * *$ & $0,114 * * *$ & $0,133 * * *$ & $0,135 * * *$ & $0,116 * *$ \\
\hline & $(0,039)$ & $(0,040)$ & $(0,041)$ & $(0,043)$ & $(0,050)$ \\
\hline \multirow[t]{2}{*}{ Расстояние до Гешера } & 0,028 & $-0,000$ & $-0,117 * *$ & $-0,116 *$ & $-0,104$ \\
\hline & $(0,000)$ & $(0,000)$ & $(0,000)$ & $(0,000)$ & $(0,000)$ \\
\hline \multirow{2}{*}{$\begin{array}{l}\text { Детей (0—4) на женщину } \\
\text { фертильного возраста } \\
\text { (15-44) }\end{array}$} & $0,355 * * *$ & $0,329 * * *$ & $0,202 * * *$ & $0,189 * * *$ & $0,165 * *$ \\
\hline & $(0,050)$ & $(0,050)$ & $(0,057)$ & $(0,058)$ & $(0,065)$ \\
\hline \multirow[t]{2}{*}{ Доля протестантов } & & $-0,147 * * *$ & $0,052 * *$ & $0,064 * *$ & 0,029 \\
\hline & & $(0,023)$ & $(0,022)$ & $(0,025)$ & $(0,031)$ \\
\hline \multirow[t]{2}{*}{ Доля мусульман } & & 0,087 & $-0,018$ & 0,009 & $-0,048$ \\
\hline & & $(0,067)$ & $(0,067)$ & $(0,069)$ & $(0,089)$ \\
\hline \multirow[t]{2}{*}{ Плотность населения } & & & $-0,012$ & $-0,015$ & \\
\hline & & & $(0,048)$ & $(0,050)$ & \\
\hline \multirow[t]{2}{*}{$\begin{array}{l}\text { (Не)сельскохозяйственный } \\
\text { сектор }\end{array}$} & & & $-0,438 * * *$ & $-0,441 * * *$ & $-0,471 * * *$ \\
\hline & & & $(0,043)$ & $(0,044)$ & $(0,051)$ \\
\hline \multirow[t]{2}{*}{$\begin{array}{l}\text { \% людей, занятых в сельском } \\
\text { хозяйстве }\end{array}$} & & & $-0,016$ & $-0,017$ & $-0,060$ \\
\hline & & & $(0,265)$ & $(0,271)$ & $(0,323)$ \\
\hline \multirow[t]{2}{*}{$\begin{array}{l}\text { \% убитых (от людей, умерших } \\
\text { внезапно) }\end{array}$} & & & & $0,065 *$ & 0,035 \\
\hline & & & & $(0,043)$ & $(0,105)$ \\
\hline
\end{tabular}




\begin{tabular}{|c|c|c|c|c|c|}
\hline 3П: Средний размер семьи & (1) & (2) & (3) & (4) & (5) \\
\hline \multirow[t]{2}{*}{$\begin{array}{l}\text { Доля людей, страдаю- } \\
\text { щих инфекционными } \\
\text { заболеваниями }\end{array}$} & & & & $0,083 * *$ & $-0,007$ \\
\hline & & & & $(0,643)$ & $(1,028)$ \\
\hline \multirow[t]{2}{*}{$\begin{array}{l}\text { Доля земли в частной } \\
\text { собственности }\end{array}$} & & & & & 0,047 \\
\hline & & & & & $(0,003)$ \\
\hline \multirow[t]{2}{*}{$\begin{array}{l}\text { Доля земли в собственности } \\
\text { крестьянских общин }\end{array}$} & & & & & 0,054 \\
\hline & & & & & $(0,003)$ \\
\hline \multirow[t]{2}{*}{ cons } & $-0,420$ & 0,069 & 0,638 & 0,220 & 0,347 \\
\hline & $(0,539)$ & $(0,642)$ & $(0,464)$ & $(0,478)$ & $(0,727)$ \\
\hline$N$ & 630 & 588 & 526 & 518 & 388 \\
\hline$R 2$ & $25 \%$ & $27 \%$ & $37 \%$ & $37 \%$ & $37 \%$ \\
\hline
\end{tabular}

Помимо сельскохозяйственного объяснения мы исследуем также другие причины различий в структуре семьи. Гипотеза о том, что расширенные домохозяйства распространены среди "неблагополучных" этносов с сильной локальной идентичностью, находит частичное подтверждение (см. табл. 3). Мы видим внушительный положительный эффект белорусского этноса и достаточно большой эффект армянского народа. Стандартизованные коэффициенты показывают, что эти два эффекта являются самыми большими в модели с этническими предикторами.

Таблица З. Влияние этносов на исторический тип семьи* (результаты МНК)

\begin{tabular}{cccc}
\hline Языки и наречия & $\begin{array}{c}\text { 3П: средний } \\
\text { размер семьи }\end{array}$ & & \\
\hline Польский & 0,037 & Латвийский язык & $0,049 * *$ \\
Славянские языки & $(1,160)$ & & $(0,174)$ \\
Немецкий язык & 0,001 & Картвельские наречия & $-0,078 * *$ \\
Еврейский язык & $(7,304)$ & & $(0,390)$ \\
Армянский язык & $0,068 * * *$ & Кавказские наречия & $-0,036$ \\
& $(0,566)$ & & $(0,657)$ \\
Таджикский язык & $-0,076$ & Финские наречия & 0,019 \\
& $(1,230)$ & & $(0,150)$ \\
& $0,226 * * *$ & Молдавский и румынский & $-0,048 * * *$ \\
& $(0,476)$ & языки & $(1,406)$ \\
& 0,055 & Наречия северных народов & $0,067 * *$ \\
& $(1,553)$ & & $(0,711)$
\end{tabular}




\begin{tabular}{|c|c|c|c|}
\hline Языки и наречия & $\begin{array}{c}\text { 3П: средний } \\
\text { размер семьи }\end{array}$ & & \\
\hline \multirow[t]{2}{*}{ Осетинский язык } & $0,058 * * *$ & Германские языки & 0,010 \\
\hline & $(1,145)$ & & $(4,721)$ \\
\hline \multirow[t]{2}{*}{ Малорусский язык } & $-0,057$ & Монголо-бурятские языки & $-0,025$ \\
\hline & $(0,132)$ & & $(20,161)$ \\
\hline \multirow[t]{2}{*}{ Белорусский язык } & $0,347 * * *$ & $\begin{array}{c}\text { Языки народов Крайнего } \\
\text { Востока }\end{array}$ & $-0,007$ \\
\hline & $(0,413)$ & & $(2,381)$ \\
\hline \multirow[t]{2}{*}{ Турецко-татарские наречия } & $-0,028$ & $\begin{array}{c}\text { Другие индоевропейские } \\
\text { языки }\end{array}$ & 0,067 \\
\hline & $(0,176)$ & & $(1,928)$ \\
\hline \multirow[t]{2}{*}{ Литовский язык } & $-0,012$ & Другие романские языки & $0,027 * *$ \\
\hline & $(0,186)$ & & $(14,843)$ \\
\hline \multirow[t]{2}{*}{ Жмудский язык } & $-0,035 * * *$ & Другие & 0,005 \\
\hline & $(0,213)$ & & $(18,772)$ \\
\hline$N$ & & 489 & \\
\hline$R$ & & $53 \%$ & \\
\hline \multicolumn{4}{|c|}{$\begin{array}{l}\text { * В таблице указаны стандартизованные коэффициенты. Робастные стандартные ошибки приведены в скобках. } \\
\text { В качестве контрольных переменных в модель включены все географические переменные, количество детей } \\
\text { (0-4) на женщину фертильного возраста (15-44), размер (не)сельскохозяйственного сектора, доля людей, за- } \\
\text { нятых в сельском хозяйстве, доля убитых от числа людей, умерших внезапно и доля страдающих инфекционными } \\
\text { заболеваниями (см. таблицу 2, спецификацию } 4 \text { за исключением религиозной принадлежности и расстояния } \\
\text { до Гешера). В качестве базовой группы взят процент людей, считающих русский язык родным. }\end{array}$} \\
\hline
\end{tabular}

Среди уездов с преобладающим белорусским этносом наибольший размер домохозяйства наблюдается в Могилевской губернии, расположенной на территории исторического региона Полесье. Сегодня Полесье разделено между четырьмя современными государствами: Белоруссией, Украиной, Россией и Польшей. Полесье было полиэтнической культурной зоной с сильной локальной идентичностью, которую населяли русские, белорусы и украинцы [Бондарчик, Браим, Бураковская, 1988]. Сильная идентичность жителей Полесья-полещуков - восходит к XIV веку, когда эта территория входила в Великое княжество Литовское и пользовалась определенной автономией. Далее, в XVI веке, часть Полесья была присоединена к Великому княжеству Московскому, а впоследствии - к Российской империи. Несмотря на тот факт, что большую часть времени Полесье было разделено между разными государствами, полещукам удалось сохранить свою идентичность вместе с обрядами и традициями.

Армения выступает следующим примером, показывающим, что сильная локальная (этническая) идентичность может коррелировать с расширенным типом семьи. Из-за своей стратегической позиции между востоком и западом Армения многократно захватывалась другими народами - персами, греками, римлянами, турками-сельджуками, тюркскими племенами и, наконец, русскими. Периоды 
независимости страны сменялись периодами ее завоевания. Сегодня Армения представляет собой независимое государство, но этнические армяне разбросаны по всему миру и хорошо известны своей крепкой диаспорой, отражающей их сильную этническую идентичность [Tölölyan, 2000].

Однако еврейские семьи не подходят под наше объяснение. В спецификации модели, где мы не используем в качестве контрольной переменной (не)сельскохозяйственный сектор, процент евреев отрицательно коррелирует с расширенной семьей. При этом корреляция исчезает, как только мы учитываем этот канал влияния. Таким образом, можно предположить, что иудаизм, стимулируя образование, торговлю и ремесла, способствовал процессам индустриализации и, тем самым, сокращению размера семьи.

Тем не менее даже после того, как мы включаем в нашу модель (не)сельскохозяйственный сектор в качестве контрольной переменной, мы не наблюдаем положительной корреляции между долей евреев и размером домохозяйства. Этому может быть несколько объяснений. Одно из них основано на том, что еврейский этнос не имел четкой географической локализации в Российской империи. Не было ни одного уезда, где евреи составляли бы большинство населения: максимальная доля данного этноса в уезде не превышала $30 \%$, а в $83 \%$ российских уездах она составляла менее $5 \%$. Столь маленький процент евреев может быть достаточным, чтобы сформировать образованный слой населения, который будет способствовать развитию несельскохозяйственных профессий в уезде и, в результате, сокращению семьи. При этом доля евреев может быть слишком мала, чтобы напрямую влиять на средний по уезду размер семьи.

Существует и другая причина, по которой положительная связь между долей евреев и размером домохозяйства может отсутствовать. Евреи редко были заняты в сельском хозяйстве, так как основными их профессиями были торговля, аренда и ремесла [Ивлева, 2017]. В результате содержание расширенной семьи для евреев было сопряжено скорее с издержками, чем с выгодами. К сожалению, дизайн нашего исследования не позволяет выявить эффект влияния этничности на структуру семьи при контроле занятости различных народов.

В остальном влияние этничности на расширенную семью обнаруживает предсказуемый паттерн. В частности, этносы, говорящие на румынском и молдавском языках, отличались меньшим размером семьи. В Молдавии и Румынии (бывшей Римской провинции) земельные наделы поровну делились между наследниками еще при жизни родителей, притом что младший сын оставался в родительском доме, а остальные дети основывали свои собственные домохозяйства [Kaser, 2009]. Таким образом, в данном регионе наблюдается смесь нуклеарных и родовых семей, которые могут уступать в размере расширенным семьям.

Средний размер домохозяйства в уездах, где преобладало немецкое население, оказался больше, чем в семьях с преобладающим русским населением. Возможно, это связано с политикой Екатерины II, которая приглашала немцев в Российскую империю прежде всего с целью модернизировать сельское хозяйство. Именно поэтому каждому переселенцу были дарованы большие земельные наделы и освобождение от налогов. Вовлеченность немцев в сельское хозяйство наряду с предоставленными льготами могли способствовать формированию рас- 
ширенных семей. Не исключено, что желание сохранить собственную идентичность путем сокращения контактов с коренным населением тоже сыграло свою роль.

Северные коренные народности отличались большим размером семьи, что может быть связано с их кочевым образом жизни. Анализ прибалтийских этносов позволяет проследить границу между делимым наследием и единонаследием, которая отделяет Латвию от Литвы [Wetherell, Plakans, 1999]. Наша модель показывает, что латвийцы, практиковавшие делимое наследие, имели бо́льшие семьи, чем русские. Напротив, домохозяйства литовцев (говорящих на жмудском языке), практикующих единонаследие, были меньше, чем у русских. Среди кавказских этносов осетины были более склонны к формированию расширенных семей (об этом см., например, [Блейх, 2015]), в то время как семьи картвельских народов были меньше, чем у русских.

Гипотеза, что чувство угрозы и экзистенциальной незащищенности обуславливает распространение расширенных семей (гипотеза 13), не противоречит нашим данным. Доля людей, страдающих от инфекционных заболеваний, положительно коррелирует с размером семьи. Второй индикатор незащищенности - процент убитых от общего количества людей, умерших случайной смертью, также положительно связан с расширенной семьей, но коэффициент статистически не значим. Мы считаем, что первая мера незащищенности более надежна, потому что доля людей, болеющих инфекционными заболеваниями в 1909 г. (благополучный год в плане эпидемиологической обстановки), значительно выше (12\%), чем доля общего количества внезапно умерших людей (0,05\%). Следовательно, инфекционные заболевания представляли бо́льшую угрозу жизни и вызывали бо́льшую незащищенность, чем преступность. Коэффициенты при обеих мерах экзистенциальной незащищенности теряют свою значимость на выборке европейской части Российской империи, что может быть связано с существенным сокращением вариации.

Дополнительным подтверждением того, что расширенные семьи возникают в условиях незащищенности, служит положительная корреляция между горным ландшафтом и размером домохозяйств. Согласно приведенному анализу существующих исследований по изучаемой тематике, возможности государства обеспечивать порядок в труднодоступных горных районах значительно ниже, а уровень преступности, соответственно, выше.

Наконец, обоснование преобладания расширенных домохозяйств у армян и жителей Полесья локальной идентичностью может быть дополнено объяснением, основанным на ощущаемой ими угрозе: “неблагополучные» этносы, пережившие за свою историю множество завоеваний и насилия, предпочитают более стабильные расширенные семьи, которые помогают им компенсировать свою незащищенность.

Далее перейдем к гипотезам, не получившим подтверждения в ходе анализа. Мы не наблюдаем ожидаемой отрицательной корреляции между долей протестантов и расширенной семьей (гипотеза 8.1). Более того, полученная корреляция оказывается положительной. С одной стороны, положительная связь может быть обусловлена определенными характеристиками людей, которые мигрировали в Российскую империю из протестантских стран. Например, многие вышеупомянутые немцы-переселенцы, имеющие больший размер семьи, были протестантами. 
С другой стороны, русские крестьяне, принявшие протестантизм, часто были более состоятельными по сравнению с крестьянами, сохранившими ортодоксальную веру [Argudiaeva, 2007]. Имея больше ресурсов, они могли позволить себе содержать семью большего размера. Гипотеза относительно иерархических религий также не находит подтверждения, так как мы не наблюдаем положительной корреляции между долей мусульман и расширенной семьей (гипотеза 8.2).

Гипотезы 12.1 и 12.2 о собственности на землю тоже не подтверждаются нашей моделью. Отсутствие статистически значимых коэффициентов говорит о том, что структура семьи не сильно различалась между территориями, где земля была в собственности крестьян или крестьянских общин, и остальными территориями.

Наконец, анализ показывает, что плотность населения не коррелирует с расширенным домохозяйством (гипотеза 11). Возможно, в силу обширной территории России давление населения было недостаточно сильным, чтобы изменить структуру семьи. В качестве альтернативы полученный результат может означать, что расширенные домохозяйства в Российской империи располагались на достаточно большом расстоянии друг от друга, что не приводило к увеличению плотности населения.

Сравнивая стандартизованные коэффициенты, можно сделать вывод, что расширенные домохозяйства в Российской империи были прежде всего ответом на потребности аграрного общества. Факторы, связанные с незащищенностью и угрозой, имеют меньшее значение, так как $\beta$-коэффициенты при переменных, отражающих природные условия для сельского хозяйства и переход от аграрного общества к индустриальному, имеют больший размер, чем $\beta$-коэффициенты при факторах экзистенциальной незащищенности. Локальная идентичность, в отличие от природных условий и климатической предрасположенности к распространению инфекций, не является экзогенным фактором, сопровождающим общество на протяжении всей истории. Она скорее связана с образованием государств и борьбой за территорию. При этом размер стандартизованных коэффициентов при переменных "армянский этнос" и "белорусский этнос" вполне сопоставим с размером таковых при "сельскохозяйственных" переменных.
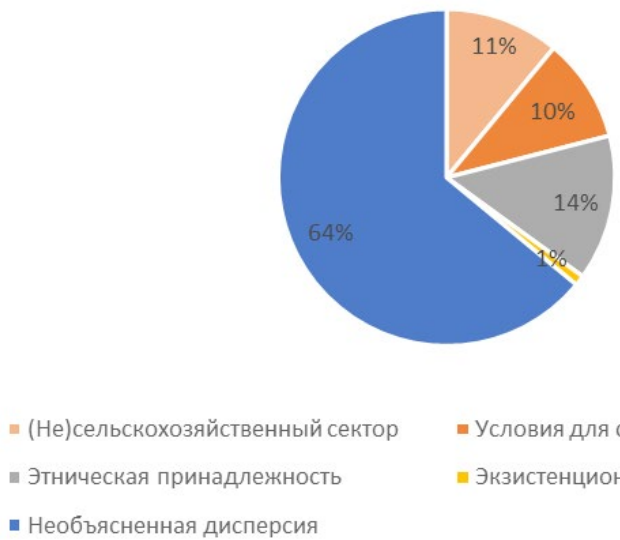

Рис. 2. Процент объясненной дисперсии за счет ключевых факторов 
Процент объясненной дисперсии в размере семьи с помощью выявленных нами причин представлен на рисунке 2. Размер (не)сельскохозяйственного сектора и условия для сельского хозяйства, отраженные на диаграмме темно- и светло-оранжевым цветом, относятся к "сельскохозяйственному" объяснению. Всего на него приходится $21 \%$ дисперсии. Этнические переменные объясняют $14 \%$ дисперсии, в то время как экзистенциальная незащищенность отвечает всего за $1 \%$ дисперсии.

\section{V. Дискуссия}

Данная работа посвящена предикторам различий между нуклеарной и расширенной семьей в прошлом. Проведенный эконометрический анализ показал, что расширенные семьи с большей вероятностью были распространены в регионах с лучшими природными условиями для возделывания земли и с большим аграрным сектором, а также на территориях, раньше перешедших к сельскому хозяйству. Это связано, во-первых, с тем, что аграрное производство было трудозатратным. Во-вторых, на протяжении истории человечества семья выступала основной производственной единицей сельскохозяйственной продукции, поэтому ее размер был крайне чувствителен к объему сельского хозяйства в экономике региона.

С некоторыми ограничениями подтверждается гипотеза, что сильная локальная (этническая) идентичность может приводить к формированию расширенных домохозяйств. Представители народов, ощущающие необходимость защищать свою идентичность, предпочитают жить большими семьями потому, что это дает возможность ограничить их контакты за пределами семьи и предотвратить ассимиляцию.

Кроме того, мы показываем, что чувство угрозы и экзистенциальной незащищенности создает благоприятные условия для формирования расширенных семей. Подобным образом в условиях бедности и высокой смертности люди пытаются застраховать себя от возможной потери кормильца и получать дивиденды за счет эффекта от масштаба.

Гипотезы о влиянии права собственности на землю, религии и плотности населения на структуру семьи не нашли подтверждения в ходе проведенного нами эконометрического анализа.

Полученные на выборке Российской империи результаты позволяют сформулировать гипотезы для будущего межстранового анализа, который мог бы дать ответ на вопрос, почему в странах Северо-Западной Европы преобладали нуклеарные семьи [Hajnal, 1965], задавшие этой части мира особую траекторию развития. Можно предположить, что северо-западноевропейский тип семьи возник в результате меньшей угрозы инфекционных заболеваний в этом регионе. В пользу данного аргумента говорит то, что страны Северо-Западной Европы имеют низкие значения индекса подверженности инфекционным болезням (Parasite Stress Index) Финхера и Торнхила [Fincher, Thornhill, 2012].

Не исключено также, что нуклеарные семьи преобладали в Северо-Западной Европе потому, что жителям этого региона не нужно было защищать свою идентичность, так как их никогда не завоевывали государства с отличным от европейского культурным и институциональным наследием, такие как Монгольская или Османская империи. 
Возможность применения "сельскохозяйственного" объяснения к распространенности нуклеарного типа домохозяйств в Северо-Западной Европе вызывает сомнения. Мы не имеем доказательств того, что природные условия для сельского хозяйства в этом регионе были существенно хуже, чем в других ${ }^{5}$. Более того, сочетание нуклеарной семьи с единонаследием, обеспечивающим свободный рынок труда лишенных земли сельскохозяйственных работников, позволяло быстро приспосабливаться к любому уровню трудозатратности сельского хозяйства. В Российской империи, как и во многих других странах мира, где каждый сын получал равную долю наследства, рынок труда был недостаточно развит. В результате регулирование размера семьи было единственным возможным механизмом адаптации к разному уровню трудозатратности экономики.

Проведенное нами исследование может служить хорошим научным заделом для изучения первопричин экономического успеха стран Северо-Западной Европы. Более того, на примере России оно позволяет проследить историческую цепочку факторов, обуславливающих формирование определенной структуры семьи и, как следствие,- региональных экономических различий.

\section{Список литературы (References)}

Блейх Н. О. Вопросы семейной организации северокавказских народов в XIXначале XX века // Вестник Ленинградского государственного университета им. А. С. Пушкина. 2015. Т. 4. № 3. С. 23-32.

Bleich N. O. (2015) Questions of the Family Organization of North-Caucasian Peoples at XIX - The Beginning of XX Centuries. Pushkin Leningrad State University Journal. Vol. 4. No. 3. P. 23-32. (In Russ.)

Бондарчик В. К., Браим И. Н., Бураковская Н. И. Полесье. Материальная культура. 1988. Кіиев: Наук. Думка.

Bondarchik V. K., Braim I. N., Burakovskaya N. I. (1988) Polessie. Materialnaya kultura. Kiev: Naukova Dumka. (In Russ.)

Ивлева Ю.А. Основные занятия еврейского населения Таврической губернии в первой половине XIX века // Россия в мировой истории, науке и культуре. 2017. C. $3-10$.

Ivleva Yu. A. (2017) Main Occupations of the Jewish Population in Tavricheskaya Gubernia in the First Half of the XIX Century. Russia in the World History, Science and Culture. P. 3-10. (In Russ.)

Alesina A., Giuliano P. (2011) Family Ties and Political Participation. Journal of the European Economic Association. Vol. 9. No. 5. P. 817-839. https://doi.org/10.1111/ j.1542-4774.2011.01024.x.

Alesina A., Giuliano P. (2014) Family Ties. In: Handbook of economic growth. Vol. 2. P. 177-215. https://doi.org/10.1016/B978-0-444-53538-2.00004-6.

\footnotetext{
${ }^{5}$ См.: Welzel C., Alexander A. C., Klasen S. (2017) The Cool Water Effect (Emerging New Monograph). URL: https://www. researchgate.net/project/The-Cool-Water-Effect-Civilizations-Turn-into-Human-Empowerment-emerging-new-monograph (дата обращения: 11.04.2021).
} 
Argudiaeva I.V. (2007) Molokans in the Amur Region. Russian Studies in History. Vol. 46. No. 3. P. 56-77. https://doi.org/10.2753/RSH1061-1983460303.

Brunnbauer U. (2003) Descent or Territoriality: Inheritance and Family Forms in the Late Ottoman and Early Post-Ottoman Balkans. In: Grandits H., Heady P. (eds.) Distinct Inheritances: Property, Family and Community in a Changing Europe. Halle Studies in the Anthropology of Eurasia. Vol. 2. Münster: LIT. P. 293-321.

Costa-Font J. (2010) Family Ties and the Crowding Out of Long-Term Care Insurance. Oxford Review of Economic Policy. Vol. 26. No. 4. P. 691-712. http://doi.org/10.1093/ oxrep/grq040.

Duranton G., Rodríguez-Pose A., Sandall R. (2009) Family Types and the Persistence of Regional Disparities in Europe. Economic Geography. Vol. 85. No. 1. P. 23-47. https:// doi.org/10.1111/j.1944-8287.2008.01002.x.

Elder G. H., Jr., Bowerman C.E. (1963) Family Structure and Child-Rearing Patterns: The Effect of Family Size and Sex Composition. American Sociological Review. Vol. 28. No. 6. P. 891-905. https://doi.org/10.2307/2090309.

Fincher C. L., Thornhill R. (2012) Parasite-Stress Promotes in-Group Assortative Sociality: The Cases of Strong Family Ties and Heightened Religiosity. Behavioral and Brain Sciences. Vol. 35. No. 2. P. 61-79. https://doi.org/10.1017/s0140525x11000021.

Fouka V. (2020) Backlash: The Unintended Effects of Language Prohibition in U.S. Schools After World War I. The Review of Economic Studies. Vol. 87. No. 1. P. 204239. https://doi.org/10.1093/restud/rdz024.

Galasso V., Profeta P. (2012) When the State Mirrors the Family: The Design of Pension Systems. London: Centre for Economic Policy Research.

Gangal K., Sarson G. R., Shukurov A. (2014) The Near-Eastern Roots of the Neolithic In South Asia. PloS One. Vol. 9. No. 5. e95714. https://doi.org/10.1371/journal. pone.0095714.

Gelfand M. (2019) Rule Makers, Rule Breakers: Tight and Loose Cultures and the Secret Signals That Direct Our Lives. London: Robinson.

Hajnal J. (1965) European Marriage Patterns in Perspective. In: Glass D., Eversley D. (eds.) Population in History. Essays in Historical Demography. Vol. I. General and Great Britain. New Brunswick: Aldine Transaction.

Inglehart R. F. (2018) Modernization, Existential Security, and Cultural Change. In: Handbook of Advances in Culture and Psychology. Vol. 7. P. 1-80.

Jha C., Panda B. (2017) Individualism and Corruption: A Cross-Country Analysis. Economic Papers. Vol. 36. No. 1. P. 60-74. https://doi.org/10.1111/1759-3441.12163.

Kaser K. (2012) The Balkan Joint Family Household: Seeking its Origins. In: Kaser K. Household and Family in the Balkans: Two Decades of Historical Family Research at University of Graz. Vol. 13. Münster: LIT. P. 109-129. https://doi.org/10.1017/ s0268416000004161. 
Kaser K. (2001) Serfdom in Eastern Europe. In: Kertzer D. I., Barbagli M. (eds.) The History of the European Family. Vol. 1. New Haven, CT: Yale University Press. P. 24-62. Kaser K. (2009) The Stem Family in Eastern Europe: Cross-Cultural and Trans-Temporal Perspectives. In: Fauve-Chamoux A., Ochiai E. (eds.) The Stem Family in Eurasian Perspective. Revisiting House Societies, $17^{\text {th }}-20^{\text {th }}$ Centuries. Bern: International Academic Publishers. P. 253-272.

Kravtsova M., Oshchepkov A. Y., Welzel C. (2018) The Shadow of the Family: Historical Roots of Social Capital in Europe. Higher School of Economics Research Paper. No. WP BRP/82/SOC/2018. https://doi.org/10.2139/ssrn.3296310.

Lipset S. M., Lenz G. S. (2000) Corruption, Culture and Markets. In: Huntington S., Harrison L. (eds.) Culture Matters: How Values Change Human Progress. New York: Basic Books. P. 112-125.

Mitterauer M. (1996) Family Contexts: the Balkans in European Comparison. The History of the Family. Vol. 1. No. 4. P. 387-406. https://doi.org/10.1016/s1081 602x(96)90009-3.

Nimkoff M. F., Middleton R. (1960) Types of Family and Types of Economy. American Journal of Sociology. Vol. 66. No. 3. P. 215-225. https://doi.org/10.1086/222873.

Pongratz C. R., Raddatz T., Claussen M. (2008) A Reconstruction of Global Agricultural Areas and Land Cover for the Last Millennium. Global Biogeochemical Cycles. Vol. 22. No. 3. https://doi.org/10.1029/2007gb003153.

Rohner D., Thoenig M., Zilibotti F. (2013) Seeds of Distrust: Conflict in Uganda. Journal of Economic Growth. Vol. 18. No. 3. P. 217-252. https://doi.org/10.1007/s10887-0139093-1.

Rosen B. C. (1961) Family Structure and Achievement Motivation. American Sociological Review. Vol. 26. P. 574-585.

Schulz J. F., Bahrami-Rad D., Beauchamp J. P., Henrich J. (2019) The Church, Intensive Kinship, and Global Psychological Variation. Science. Vol. 366. No. 6466. eaau5141. https://doi.org/10.1126/science.aau5141.

Todd E. (1990) L'invention de l’Europe. Paris: Seuil.

Todorova M. (1989) Myth-Making in European Family History: The Zadruga Revisited. East European Politics and Societies. Vol. 4. No. 1. P. 30-76. https://doi.org/10.11 $77 / 0888325490004001003$.

Treisman D. (2000) The Causes of Corruption: a Cross-National Study. Journal of Public Economics. Vol. 76. No. 3. P. 399-457. https://doi.org/10.1016/s0047-2727(99) 00092-4.

Tölölyan K. (2000) Elites and Institutions in the Armenian Transnation. Diaspora: A Journal of Transnational Studies. Vol. 9. No. 1. P. 107-136. https://doi.org/10.1353/ dsp.2000.0004. 
Uslaner E. M. (2000) Producing and Consuming Trust. Political Science Quarterly. Vol. 115. No. 4. P. 569-590. https://doi.org/10.2307/2657610.

Wall R. (1983) Does Owning Real Property Influence the Form of the Household? An Example from Rural West Flanders. In: Wall R., Robin J., Laslett P. (eds.) Family Forms in Historic Europe. P. 379-408. https://doi.org/10.1017/cbo9780511897535.013.

Webster S. (1973) Native Pastoralism in the South Andes: Civilization's Turn Into Human Empowerment. Ethnology. Vol. 12. No. 2. P. 115-133. https://doi.org/10.2307/ 3773341.

Wetherell C., Plakans A. (1999) Borders, Ethnicity, and Demographic Patterns in the Russian Baltic Provinces in the Late Nineteenth Century. Continuity and Change. Vol. 14. No. 1. P. 33-56. https://doi.org/10.1017/s0268416099003252. 
Приложение

Таблица. Сводная статистика по ключевым переменным

\begin{tabular}{|c|c|c|c|c|c|}
\hline Название переменной & $N$ & Среднее & $\begin{array}{c}\text { Станд. } \\
\text { отклонение }\end{array}$ & Минимум & Максимум \\
\hline Средний размер семьи & 751 & 5.185 & 0,857 & 1,983 & 11,524 \\
\hline Возвышенность & 829 & 291,842 & 429,619 & $-9,182$ & 3977,456 \\
\hline Пригодность почвы & 829 & 40,105 & 21,560 & 0 & 82,175 \\
\hline $\begin{array}{l}\text { Средняя температура } \\
\text { в самый теплый период года }\end{array}$ & 683 & 25,037 & 3,09262 & 15 & 39 \\
\hline $\begin{array}{l}\text { Средние осадки в самый } \\
\text { влажный период }\end{array}$ & 683 & 28,780 & 9,008 & 0 & 59 \\
\hline $\begin{array}{l}\text { Плотность населения, } \\
\text { человек/км² }\end{array}$ & 761 & 41,200 & 50,433 & 0,006 & 759,851 \\
\hline $\begin{array}{l}\text { Доля земли, покрытой лесом } \\
\text { в досредневековые времена }\end{array}$ & 759 & 0,319 & 0,253 & 0 & 0,923 \\
\hline Доля ортодоксальных христиан & 715 & 69,371 & 36,661 & 0,071 & 99,962 \\
\hline Доля протестантов & 715 & 3,754 & 14,826 & 0 & 97,329 \\
\hline Доля мусульман & 715 & 12,603 & 28,209 & 0 & 99,882 \\
\hline Менее 50 км до ближайшей реки & 828 & 0,231 & 0,422 & 0 & 1 \\
\hline $\begin{array}{l}\text { Доля земли в частной } \\
\text { собственности }\end{array}$ & 482 & 37,041 & 16,927 & 0 & 80 \\
\hline $\begin{array}{l}\text { Доля земли в собственности } \\
\text { крестьянских общин }\end{array}$ & 484 & 44,071 & 15,664 & 0,1 & 89,9 \\
\hline Доля казенных земель & 453 & 11,723 & 20,173 & 0 & 99,9 \\
\hline Доля удельных земель & 484 & 1,691 & 6,103 & 0 & 68,7 \\
\hline $\begin{array}{l}\text { (Не)сельскохозяйственный } \\
\text { сектор (главная компонента } \\
\text { от грамотности и урбанизации) }\end{array}$ & 765 & 0 & 1 & $-1,372$ & 5,884 \\
\hline $\begin{array}{l}\text { Главная компонента от доли } \\
\text { убитых женщин и доли убитых } \\
\text { мужчин (от общего числа женщин } \\
\text { и мужчин, умерших внезапно) }\end{array}$ & 86 & 0 & 1 & $-0,747$ & 5,215 \\
\hline $\begin{array}{l}\text { Доля людей, страдающих } \\
\text { инфекционными заболеваниями }\end{array}$ & 91 & 0,117 & 0,057845 & 0,012 & 0,308 \\
\hline Расстояние до Гешера (км) & 820 & 2691,886 & 1167,591 & 1076,006 & 9317,958 \\
\hline
\end{tabular}




\begin{tabular}{|c|c|c|c|c|c|}
\hline Название переменной & $N$ & Среднее & $\begin{array}{c}\text { Станд. } \\
\text { отклонение }\end{array}$ & Минимум & Максимум \\
\hline Польский язык & 667 & 0,008 & 0,026 & 0 & 0,348 \\
\hline Славянские языки & 667 & 0,001 & 0,011 & 0 & 0,213 \\
\hline Немецкий язык & 667 & 0,008 & 0,029 & 0 & 0,403 \\
\hline Еврейский язык & 667 & 0,025 & 0,049 & 0 & 0,283 \\
\hline Армянский язык & 667 & 0,015 & 0,077 & 0 & 0,855 \\
\hline Таджикский язык & 667 & 0,001 & 0,025 & 0 & 0,509 \\
\hline Осетинский язык & 667 & 0,001 & 0,028 & 0 & 0,654 \\
\hline Малорусский язык & 667 & 0,139 & 0,285 & 0 & 0,980 \\
\hline Белорусский язык & 667 & 0,049 & 0,186 & 0 & 0,899 \\
\hline Татский язык & 667 & 0,118 & 0,259 & 0 & 0,992 \\
\hline Литовский язык & 667 & 0,006 & 0,053 & 0 & 0,722 \\
\hline Жмудский язык & 667 & 0,003 & 0,051 & 0 & 0,803 \\
\hline Латышский язык & 667 & 0,019 & 0,121 & 0 & 0,943 \\
\hline Картвельские наречия & 667 & 0,015 & 0,110 & 0 & 0,985 \\
\hline Турецко-татарские наречия & 667 & 0,118 & 0,259 & 0 & 0,992 \\
\hline Кавказские наречия & 667 & 0,019 & 0,122 & 0 & 0,997 \\
\hline Финские наречия & 667 & 0,039 & 0,141 & 0 & 0,971 \\
\hline Монголо-бурятские наречия & 667 & 0,002 & 0,033 & 0 & 0,735 \\
\hline Наречия северных племен & 667 & 0,009 & 0,079 & 0 & 0,988 \\
\hline Германские языки & 667 & 0,0001 & 0,002 & 0 & 0,056 \\
\hline Молдавский и румынский языки & 667 & 0,006 & 0,059 & 0 & 0,778 \\
\hline Языки народов Дальнего Востока & 667 & 0,001 & 0,017 & 0 & 0,362 \\
\hline $\begin{array}{l}\text { Детей }(0-4) \text { на женщину } \\
\text { фертильного возраста }\end{array}$ & 762 & 0,722 & 0,035 & 0,538 & 0,936 \\
\hline
\end{tabular}

